\title{
PAJAK SEBAGAI SUMBER PENDANAAN PEMBANGUNAN DAERAH DIKABUPATEN GOWA
}

\author{
INTAN SAKINAH AULIAH, MARILANG \\ Fakultas Syariah dan Hukum Universitas Islam Negeri Alauddin Makassar
}

\begin{abstract}
Abstrak
Upaya yang dilakukan Pemerintah Daerah Gowa dalam mengoptimalkan penerimaan pajak diawali dengan menyusun kebijakannya yang tertuang dalam dokumen perencanaan, selain itu Pemerintah Daerah Gowa juga melakukan survey ke berbagai daerah di Kabupaten Gowa untuk mencari objek pajak yang belum terdaftar sebagai wajib pajak untuk kemudian dijadikan wajib pajak. Peranan pajak dalam pembangunan daerah di Kabupaten Gowa memiliki peranan yang paling penting, hal tersebut dibuktikan dengan jumlah pendapatan dari pajak yang lebih dominan dibandingkan dengan sumber pendapatan asli daerah lainnya yang ada di Kabupaten Gowa. Pajak dapat dijadikan sumber pendanaan pembangunan di kabupaten Gowa ditinjau dari hukum tata negara Islam karena pada masa kepemimpinan para sahabat-sahabat Rusulullah saw pun menerapkan pajak sebagai sumber pendanaan pembangunan bagi negeri yang mereka pimpin.
\end{abstract}

\section{Kata Kunci : Pajak, Pembangunan Daerah, Pendanaan.}

\begin{abstract}
Efforts made by the Gowa Regional Government in optimizing tax revenue begin with compiling its policies contained in the planning document, besides the Gowa Regional Government also conducts surveys to various regions in Gowa Regency to look for tax objects that haven't been registered as taxpayers and then become taxpayers. The role of taxes in regional development in Gowa Regency has the most important role, this is evidenced by the amount of tax revenue that is more dominant compared to other original regional revenue sources in Gowa Regency. Taxes can be used as a source of development funding in Gowa district in terms of Islamic state administration law because during the leadership of the friends of Rasulullah saw also applied tax as a source of development funding for the country they lead.
\end{abstract}

Keywords: Taxes, Funding, Regional Development. 


\section{A. PENDAHULUAN}

Indonesia merupakan negara kesatuan yang menerapkan sistem otonomi kepada daerah atau disebut juga dengan sistem desentralisasi yang sedikit mirip dengan negara serikat atau federal. Intervensi pemerintah pusat yang terlalu besar di masa lalu telah menimbulkan masalah rendahnya kapabilitas dan efekivitas pemerintah daerah dalam mendorong proses pembangunan dan kehidupan demokrasi di daerah, arahan yang terlalu besar dari pemerintah pusat tersebut menyebabkan inisiatif dan prakarsa daerah cenderung mati sehingga pemerintah daerah seringkali menjadikan pemenuhan peraturan sebagai tujuan, dan bukan sebagai alat untuk meningkatkan pelayanan kepada masyarakat. ${ }^{1}$

Salah satu faktor penting dalam pelaksanaan otonomi daerah ialah menyangkut ekonomi atau keuangan daerah. Dengan adanya kemampuan daerah secara ekonomis, maka daerah dapat berdiri sendiri tanpa ketergantungan dengan pusat. Sasaran otonomi daerah bukan sumber asli penerimaan daerah untuk mendukung Anggaran Pendapatan dan Belanja Daerah (APBD), tetapi kebebasan yang lebih besar untuk menentukan penggunaannya. Agar pelaksanaan tugas otonomi dapat berjalan dengan baik, maka yang perlu diperhatikan ialah sumber pendapatan daerah, tekhnologi, struktur pemerintahan daerah, dukungan hukum, perilaku masyarakat, dan faktor pemimpin. ${ }^{2}$

Dalam rangka meningkatkan kemampuan keuangan daerah agar dapat melaksanakan otonomi, pemerintah melakukan berbagai kebijakan perpajakan daerah, diantaranya dengan menetapkan UU NO. 34 Tahun 2000 tentang perubahan atas UU.No. 18 Tahun 1997 tentang Pajak Daerah dan Retribusi Daerah. Pemberian kewenangan dalam pengenaan pajak daerah dan retribusi daerah, diharapkan dapat lebih mendorong Pemerintah Daerah terus berupaya untuk mengoptimalkan Pendapatan Asli Daerah (PAD), khusunya yang berasal dari pajak daerah dan retribusi daerah. Jadi peranan pajak pada dasarnya untuk mengoptimalkan PAD yang nantinya akan digunakan untuk pembangunan daerah.

Pendapatan Asli Daerah (PAD) terdiri dari:

a. Pajak Daerah;

b. Retribusi Daerah;

c. Hasil pengelolaan kekayaan yang dipisahkan;

d. Lain-lain PAD yang sah menurut UU. ${ }^{3}$

Wajar bila peningkatan PAD dijadikan salah satu indikator kesiapan daerah dalam menjalankan kebijakan otonomi. Apalagi otonomi telah memberikan keleluasaan dalam kewenangan, penataan organisasi, dan pengelolaan keuangan. Jadi, yang harus diperhatikan adalah pengenaan pajak dan retribusi hendaknya seiring dengan tingkat pendapatan masyarakat serta pelayanan yang diberikan oleh pemerintah daerah. Selain itu, peningkatan PAD juga secara agregat harus seiring dengan Pertumbuhan Domestik Regional Bruto (PDRB). ${ }^{4}$

\footnotetext{
${ }^{1}$ Mardiasmo, Otonomi dan Manajemen Keuangan Daerah, (Percetakan Andi Ofset), h.4.

${ }^{2}$ Adrian Sutedi, Hukum Pajak dan Retribusi Daerah, (Bogor: Ghalia Indonesia), h.10-11.

${ }^{3}$ Yuzwar Zainul Basri dan Mulyadi Subri, Keuangan Negara dan Analisis Kebijakan Utang Luar Negeri, (Ed. 1. Cet.1; Jakarta: PT RajaGrafindo Persada, 2003), h.65.

${ }^{4}$ Adrian Sutedi, Hukum Pajak dan Retribusi Daerah, (Cet. I; Bogor Selatan: Ghalia Indonesia,
} 2008), h.5. 
Pajak daerah merupakan instrument keuangan konvensional yang sering digunakan di banyak negara. Penerimaan pajak digunakan untuk membiayai prasarana dan pelayanan perkotaan yang memberikan manfaat bagi masyarakat umum yang biasa juga disebut dengan public goods. Penerimaan pajak dapat digunakan untuk membiayai satu dari tiga pengeluaran di bawah ini,yaitu:

a. Untuk membiayai investasi total;

b. Untuk membiayai pembayaran hutang ;

c. Menambah dana cadangan yang dapat digunakan untuk investasi di masa depan

Pajak merupakan sumber utama penerimaan negara yang digunakan untuk membiayai pengeluaran negara. Untuk melaksanakan pembangunan dibutuhkan dana yang tidak sedikit,dan salah satu sumber utama dari dana yang tidak sedikit tersebut ditopang melalui penerimaan pajak. Oleh karena itu,pajak sangat dominan dalam menopang pembangunan nasional dari segala sektor. ${ }^{5}$

Bagi pemerintah daerah, penerimaan pajak yang terpenting dan dominan ialah yang bersumber dari pajak pembangunan, pajak reklame, dan pajak hiburan/tontonan. Selain itu, pajak bumi dan bangunan yang pada dasarnya merupakan penerimaan bagi hasil dari pemerintah pusat kepada pemerintah daerah dapat dianggap sebagai sumberpenerimaan pajak yang utama bagi daerah. Oleh karena itu, pajak bumi dan bangunan sering bersama-sama dengan PAD dikategorikan sebagai penerimaan daerah sendiri. ${ }^{6}$

Sesuai dengan ketentuan pasal 23 ayat (2) Undang-Undang Dasar 1945,ketentuanketentuan pajak yang merupakan landasan pemungutan pajak ditetapkan dengan Undang-Undang. Undang-Undang nomor 12 tahun 1985 tentang Pajak Bumi dan Bangunan (PBB) yang berlaku sejak tahun 1986 merupakan landasan hukum dalam pengenaan pajak sehubungan dengan hak atas bumi dan bangunan/atau perolehan manfaat atas bangunan.

Setelah hampir satu dasawarsa berlakunya Undang-Undang Nomor 12 Tahun 1985, dengan makin meningkatnya kesejahteraan masyarakat dan meningkatnya jumlah objek pajak serta untuk menyelaraskan pengenaan pajak dengan amanat dalam Garis-garis Besar Haluan Negara (GBHN), dirasakan sudah masanya untuk menyempurnakan Undang-Undang Nomor 12 Tahun 1985. Dengan berpegang teguh pada prinsip kepastian hukum dan keadilan, maka arah dan tujuan penyempurnaan Undang-Undang ini adalah sebagai berikut:

a. Menunjang kebijaksanaan pemerintah menuju kemandirian bangsa dalam pembiayaan pembangunan yang sumber utamanya berasal dari penerimaan pajak;

b. Lebih memberikan kepastian hukum dan keadilan bagi masyarakat untuk berpartisipasi dalam pembiayaan pembangunan sesuai dengan kemampuannya.

Adapun menurut Undang-Undang Nomor 6 Tahun 1983 Tentang Ketentuan Umum dan Tata Cara Perpajakan sebagaimana telah diubah terakhir dengan Undang- Undang Nomor 16 tahun 2009 dalam pasal 1 berbunyi "Pajak daerah adalah iuran wajib yang dilakukan oleh orang pribadi atau badan kepada daerah tanpa imbalan langsung yang seimbang, yang dapat dipaksakan berdasarkan peraturan perundang- undangan yang

\footnotetext{
${ }^{5}$ Md. Krisna Arta Anggar Kusuma dan Ni Gst. Putu Wirawati, E-jurnal akuntansi Universitas Udayan, 5.3 (2013); 574-585 (03 maret 2017)

${ }^{6}$ Susiyati B. Hirawan, "Pembiayaan Pembangunan Perkotaan Melalui Pemanafaatan Instrumen Keuangan", dalam Adrian Sutedi Hukum Pajak Dan Retribusi Daerah, (Bogor: Ghalia Indonesia), h. 5-6.
} 
berlaku, yang digunakan unuk membiayai penyelenggaraan pemerintahan daerah dan pembangunan daerah."

Kriteria pajak daerah selain yang ditetapkan Undang-Undang bagi Kabupaten/Kota adalah:

a. Bersifat pajak dan bukan retribusi;

b. Objek pajak terletak atau terdapat di wilayah Kabupaten/Kota yang bersangkutan dan mempunyai mobilitas yang cukup rendah serta hanya melayani masyarakat di wilayah Kabupaten/Kota yang bersangkutan;

c. Objek dan dasar pengenaan pajak tidak bertentangan dengan kepentingan umum;

d. Objek pajak bukan merupakan objek pajak Provinsi dan/atau objek pajak pusat;

e. Potensinya memadai;

f. Tidak memberikan dampak ekonomi yang negatif;

g. Memerhatikan aspek keadilan dan kemampuan masyarakat; dan

h. Menjaga kelestarian lingkungan. ${ }^{7}$

Sebenarnya kebijakan fiskal telah sejak lama dikenal dalam teori ekonomi Islam, yaitu sejak zaman Rasūlullah saw dan khulafā Al-Rāsyidūn dan kemudian dikembangkan oleh para ulama namun pajak pada zaman Rasulullah Shallallahu 'alaihi wa sallam tidak pernah diwajibkan atas kaum muslimin, dan pajak hanya diwajibkan atas orang-orang kafir saja. ${ }^{8}$

Dalam istilah bahasa Arab, pajak dikenal dengan namal-'usyr atau al-maks, atau bisa juga disebut al-d̄aribah, yang artinya adalah: "Pungutan yang ditarik dari rakyat oleh para penarik pajak". Atau suatu ketika bisa disebut al-kharāj, akan tetapi al-kharāj biasa digunakan untuk pungutan-pungutan yang berkaitan dengan tanah secara khusus. Sedangkan para pemungutnya disebut șahibual-maks atau al-asyarh. Ketentuanketentuan syar' $\overline{1}$, baik yang tertuang di dalam Al-Qur'an maupun Hadits nabi saw, yang mengatur tentang pajak secara langsung memang tidak ada, yang ada adalah alsar para sahabat yang berbentuk praktek penyelanggaraan negara yang dilaukan oleh Khulafa AlRasydun, sejak Umaru ibn Khatab. Itupun terbatas pada pajak yang wajib dibayarkan oleh warga negara non muslim yang menggarap tanah negara.

Para ulama sendiri memiliki pandangan berbeda terhadap diberlakukannya pajak sebagai sumber pendapatan daerah namun ada juga yang menyetujui diberlakukannya pajak sebagai sumber pendapatan daerah.

Pajak yang diwajibkan oleh penguasa muslim karena keadaan darurat untuk memenuhi kebutuhan negara atau untuk mencegah kerugian yang menimpa, sedangkan perbendaharaan negara tidak cukup dan tidak dapat menutupi biaya kebutuhan tersebut, maka dalam kondisi demikian ulama telah memfatwakan bolehnya menetapkan pajak atas orang-orang kaya dalam rangka menerapkan maslahah al-mursalah dan berdasarkan kaidah "tafwit adnā al-maslahatyn tașhīlan lì a'lāhumā" (sengaja tidak mengambil mashlahat yang lebih kecil dalam rangka memperoleh mashalat yang lebih besar) dan "yatahammalu adl-dlarar al-khās li daf'I dlararin 'àm" (menanggung kerugian yang lebih ringan dalam rangka menolak kerugian yang lebih besar).

\section{B. METODE PENELITIAN}

\footnotetext{
${ }^{7}$ Ahmad Yani, Hubungan Keungan Antara Pemerintah Pusat dan Daerah di Indonesia, edisi revisi dan diperluas, (n.p.:Rajawali Pers, 2003), h.52-53.

${ }^{8}$ Adiwarman A. Karim, Ekonomi Makro Islam, (Jakarta: Rajawali Pers), h.285.
} 
Metode Penelitian yang digunakakan adalah kualiatif dengan pendekatan penelitian yang digunakan adalah: pendekatan sosiologis. Adapun sumber data penelitian ini adalah sumber data primer dengan wawancara langsung ke lapangan dan data sekunder melalui studi kepustakaan dan Undang-Undang. Selanjutnya metode pengumpulan data yang digunakan adalah wawancara dan dokumentasi. Lalu, teknik pengolahan dan analisis data dilakukan dengan tahap: klasifikasi data, reduksi data, coding data, editing data, analisis data.

\section{PEMBAHASAN}

\section{Upaya Pemerintah Gowa dalam Mengoptimalkan Penerimaan Pajak}

Dengan pola kebijakan yang tepat untuk meningkatkan kemampuan keuangan daerah, pertumbuhan komponen pajak daerah, retribusi daerah, dan hasil usaha daerah akan menjadi faktor yang penting dalam mendorong pertumbuhan PAD nanti. Sedangkan, untuk dana perimbangan dan komponen bagi hasil pajak provinsi merupakan dua unsur yang penting dalam mendorong pertumbuhan dana perimbangan yang akan diperoleh nantinya.

Masih kecilnya kontribusi pendapatan asli daerah sebagai barometer tingkat kemandirian daerah dalam menjalankan amanat otonomi daerah, mengharuskan pemerintah daerah secara terus menerus berupaya meningktakan pendapatan asli daerah sebagai sumber utama pendapatan daerah, dimana dapat dipertanggungjawabkan dengan memerhatikan kondisi masyarakat yang menjadi subjek pendapatan asli daerah.

Prinsip dasar pengelolaan kekayaan (aset) daerah meliputi tiga hal utama, yaitu:

a. Adanya perencanaan yang tepat;

b. Pelaksanaan atau pemanfaatan secara efisien dan efektif;

c. Pengawasan (monitoring).

1. Perencanaan

Untuk melaksanakan apa yang menjadi kewenangan wajibnya (Tupoksi) pemerintah daerah memerlukan barang atau kekayaan untuk menunjang pelaksaan tugas dan kewenangannya. Untuk itu, pemerintah daerah perlu membuat perencanaan kebutuhan aset yang akan digunakan/dimiliki. Berdasarkan rencana tersebut, pemerintah daerah kemudian mengusulkan anggaran pengadaannya. Dalam hal ini, masyarakat dan Dewan Perwakilan Rakyat Daerah (DPRD) perlu melakukan pengawasan mengenai apakah aset kekayaan yang direncanakan untuk dimiliki tersebut sudah benar-benar dibutuhkan atau tidak oleh daerah. Seandainya memang dibutuhkan, maka pengadaannya harus dikaitkan dengan cakupan layanan yang dibutuhkan dan diawasi apakah ada mark-up dalam pembelian tersebut. Setiap pembelian barang atau aset baru harus dicatat dan terdokumentasi dengan baik dalam sistem database kekayaan daerah.

Pengadaan barang atau kekayaan daerah harus dilakukan berdasarkan sistem tender (Compulsory Competitive Tendering Contract). Hal tersebut dilakuakan supaya pemerintah daerah dan masyarakat tidak dirugikan. Selain itu DPRD dituntut lebih tegas dan cermat dalam mengawasi proses perencanaan pengadaan kekayaan daerah.

Pada dasarnya, kekayaan daerah dapat diklasifikasikan menjadi dua jenis, yaitu:

1) Kekayaan yang sudah ada (eksis) sejak adanya daerah tersebut. Kekayaan jenis ini meliputi seluruh kekayaan alam dan geografis seluruh kewilayahannya. Contonya adalah tanah, hutan, tambang, gunung, danau, pantai dan laut, sungai, dan peninggalan bersejarah. 
2) Kekayaan yang akan dimiliki baik yang berasal dari pembelian maupun yang akan dibangun sendiri. Kekayaan jenis ini berasal dari pembelian maupun yang akan dibangun sendiri. Kekayaan jenis ini berasal dari aktivitas pemerintah daerah yang didanai dari APBD serta kegiatan perekonomian daerah lainnya. Contonya adalah jalan, jembatan, kendaraan, dan barang modal lainnya.

Pemerintah daerah harus membuat perencanaan yang tepat terhadap dua jenis kekayaan tersebut. Perencanaan juga meliputi perencanaan terhadap aset yang belum dimanfaatkan atau masih berupa aset potensial. Perencanaan yang dilakukan harus memperhatikan 3 hal, yaiu melihat kondisi aset daerah di masa lalu, aset yang dibutukan di masa sekarang, dan perencanaan kebutuan daerah di masa yang akan datang. Pemerintah daerah perlu menetapkan standar kekayaan minimum yang harus dimiliki daerah untuk dapat memenuhi cakupan pelayanan yang dibutuhkan masyarakat. Oleh karena itu perlu dibuat perencanaan strategi baik yang bersifat jangka pendek, menengah maupun jangka panjang mengenai pengelolaan aset daerah. Dalam hal ini perlu dibuat/ditetapkan indikator kinerja pengelolaan kekayaan daerah. Indikator pengelolaan daerah tersebut sangat penting untuk menilai kinerja pemerintah daerah dalam mengelola kekayaan daerah serta memberi petunjuk/arah bagi pemerintah daerah untuk bertindak agar terhindar dari reaksi negatif yang merugikan masyarakat, misalnya kerusakan lingkungan dan keurasakan budaya.

Hal tersebut sejalan dengan apa yang disampaikan Bapak Drs. Hasanuddin BM, selaku sekretaris di Kantor Badan Pendapatan Daerah yang ditemui di kantornya pada tanggal 14 Agustus 2017. Beliau mengatakan bahwa

"upaya Pemda Gowa dalam mengoptimalkan peningkatan pajak, diawali dengan menyusun kebijakannya yang tertuang dalam dokumen perencancanaan, ada namanya RPCMB dikatakan bahwa salah satu kebijakan yang dibuat oleh pemerintah terkait dengan $\mathrm{PAD}$ adalah bahwasanya pemerintah daerah harus meningkatkan PAD dalam daerahnya, inilah yang kemudian menjadi rujukan bagi SKPD pengelola PAD termasuk Bapenda (Badan Pendapatan Daerah) bagaimana upayanya untuk meningkatkan hal tersebut. ${ }^{9}$

Adapun yang diungkapkan oleh Bapak Drs. Hasanuddin BM, tersebut mengenai perencanaan yang dilakukan di Kabupaten Gowa dapat kita lihat pada tabel berikut:

\section{Tabel 1:}

Perencanaan Pendapat Daerah di Kabupaten Gowa Tahun 2016 sesuai dengan Unit Kerja yang ada di Kabupaten Gowa

\begin{tabular}{|c|c|c|c|c|}
\hline \multirow{2}{*}{ No } & \multirow{2}{*}{ PENGELOLA/UNIT KER.IA } & \multicolumn{2}{|c|}{ TARGET PAD } & \multirow{2}{*}{ REALISASI } \\
\hline & & POKOK & PERUBAHAN & \\
\hline$\frac{1}{1}$ & Dinas Sosial, Tenaga Kerja \& Transmigrasi & $25,000,000.00$ & $25,000,000.00$ & $28,980,000.00$ \\
\hline 2 & Dinas Pengelolaan Keuangan Daerah & $71,648,525,241.00$ & $78,013,865,241.00$ & $94,972,420,182.80$ \\
\hline 3 & Bagian Administrasi Pemerintahan Umum & $15,000,000,00$ & $15,000,000,00$ & $15,000,000.00$ \\
\hline 4 & Perusahaan Daerah Holding Compani & $1,000,000,000,00$ & $500,000,000,00$ & \\
\hline 5 & PDAM & $125,000,000,00$ & $125,000,000.00$ & $150,000,000.00$ \\
\hline 6 & Kantor Pelayanan Terpadu & $345,000,000.00$ & $3,575,000.000$ & $424,885,874.00$ \\
\hline 7 & Kantor Satuan Pramong Praja & $300,00,000.00$ & $325,000,000,00$ & $467,150,000.00$ \\
\hline 8 & Dinas Kehutanan dan Perkebenunan & $280,000,000.00$ & $350,000,000.00$ & $350,000,500.00$ \\
\hline 9 & Bagaan Umum & $51,100,000.00$ & $51,100,000,00$ & $75,260,000.00$ \\
\hline 10 & Bagian Administrasi Pembangunan & $1,000,000,00$ & $1,000,000,00$ & \\
\hline 11 & Dinas Kebudayaan dan Pariwisata & $1,165,000,000.00$ & $1,915,000,000.00$ & $2,315,289,825,00$ \\
\hline 12 & Dinas Kelautan, Perikanan \& Peternakan & $148,000,000.00$ & $158,000,000.00$ & $168,787,000.00$ \\
\hline 13 & Pekerjaan Umum (PU) & $2,714,200,000.00$ & $3,264,000,000.00$ & $3,463,009,816,00$ \\
\hline 14 & Bagian Administrasi Perekonomian & $300,000,000,00$ & $300,000,000,00$ & $297,000,000.00$ \\
\hline 15 & Dinas Perhubungan, Komunikasi \& Informatika & $849,640,000,00$ & $853,220,000,00$ & $1,004,635,200.00$ \\
\hline 16 & Dinas Kependudukan \& Catatan Sipil & & & \\
\hline 17 & Dina Pertambangan \& Energi & $2,235,000,000,00$ & $2,235,000,000.000$ & $746,222,309.00$ \\
\hline 18 & Rumah Sakit Umum & $52,800,000,000.00$ & $54,400,000,000,00$ & $53,199,883,225,00$ \\
\hline 19 & Dinas Keschatan & $25,977,008,736,00$ & $25,977,008,736.00$ & $42,586,883,257,00$ \\
\hline & TOTAL PENERIMAAN PAD & $159,679,473,977.00$ & $168,511,768,977,00$ & $200,265,407,188.80$ \\
\hline
\end{tabular}


Sumber: Laporan Target \& Realisasi Pendapatan Asli Daerah (PAD) di Kabupaten Gowa 2. Pelaksanaan

Apabila sudah dilakukan perencanaan secara tepat, permasalahan berikutnya adalah bagaimana pelaksanaannya. Kekayaan milik daerah harus dilakukan secara optimal dengan memperhatikan prinsip efisiensi, efektifitas, transpalansi, dan akuntabilitas publik. Masyarakat dan DPRD juga harus melakukan pengawasan terhadap pemanfaatan aset daerah terebut agar tidak terjadi penyalahgunaan kekayaan milik daerah. Pengelolaan juga menyangkut pendistribusian, pengamanan dan perawatan. Perlu ada unit pengelola kekayaan yang profesional agar tidak terjadi overlapping tugas dan kewenangan dalam mengelola kekayaan daerah. Pengamanan terhadap kekayaan daerah harus dilakukan secara memadai baik pengamanan fisik maupun sistem akuntansi (sistem pengendalian intern).

Hal yang cukup penting diperhatikan pemerintah adalah perlunya dilakukan perencanaan terhadap Biaya Operasi dan Pemeliharaan untuk setiap kekayaan yang dibeli atau diadakan. Hal ini disebabkan karena seringkali biaya Operasi dan pemeliharaan tidak dikaitkan dengan belanja/investasi modal.

Pengelolaan kekayaan daerah harus memenuhi prinsip akuntabilitas publik. Akuntabilitas publik yang harus dipenuhi paling tidak meliputi:

a. Akuntabilitas kejujuran dan akuntabilits hukum;

b. Akuntabilitas proses;

c. Akuntabilitas kebijakan.

Adapun menurut Bapak Drs. Hasanuddin BM mengenai pelaksanaan peningkatan PAD atau penerimaan pajak oleh Pemda Gowa dapat dilakukan dengan 2 cara yaitu:

a. Intensifikasi, yakni bagaimana cara agar pemerintah dapat mengoptimalkan potensi daerah yang sudah ada; Intensifikasi pajak adalah peningkatan intensitas pungutan terhadap suatu subyek dan obyek pajak yang potensial, namun belum tergarap atau terjaring pajak serta memperbaiki kinerja pemungutan gara dapat mengurangi kebocoran-kebocoran yang ada. Upaya intensifikasi dapat ditempuh melalui 3 cara yaitu:

1) Penyempurnaan administrasi pajak;

2) Peningkatan mutu pegawai atau petugas pemungutan

3) Penyempurnaan undang-undang pajak

b. Ekstensifikasi pajak yaitu upaya memperluas subyek dan obyek pajak serta penyesuaian tarif. Ekstensifikasi pajak antara lain dapat ditempuh melalui 3 cara, yaitu:

1) Perluasan wajib pajak;

2) Penempurnaan tarif;

3) Perluasan Objek pajak. ${ }^{10}$

3. Pengawasan

Pengawaan yang ketat perlu dilakukan sejak tahap perencanaan hingga penghapusan aset. Dalam hal ini peran pemerintah dan masyarakat serta auditor internal sangat penting. Keterlibatan auditor internal dalam proses pengawasan ini sangat penting untuk

${ }^{10}$ Hasanuddin, Sekretaris Kantor Badan Pendapatan Daerah Kabupaten Gowa, wawancara, 14 Agustus 2017. 
menilai konsistensi antara praktik yang dilakukan pemerintah daerah dan standar yang berlaku.

Dengan semakin tingginya pertumbuhan ekonomi, maka semakin tinggi pula penghasilan dari transaksi bisnis yang dilakukan oleh masyarakat, sehingga pajak dalam negeri yang bisa dihimpun semakin tinggi. Demikian sebaliknya terjadi apabila tingkat pertumbuhan ekonomi menurun.

Asumsi inflasi mempengaruhi sisi pendapatan negara pada penerimaan pajak dalam negeri. Dengan semakin tingginya tingkat inflasi maka penerimaan pajak dalam negeri akan semakin tinggi, dan sebaliknya.

Asumsi nilai tukar terhadap valuta asing mempengaruhi sisi pendapatan negara pada penerimaan pajak dalam negeri, pajak perdagangan internasional dan penerimaan sumber daya alam, terutama migas.Asumsi harga minyak mentah di pasar internasional dan produksi minyak mentah dalam negeri sangat berpengaruh terhadap penerimaan sumber daya alam, terutama minyak bumi dan gas alam akan mempengaruhi PPh migas

Strategi lainnya dalam menentukan besaran penerimaan pajak yaitu membandingkan dengan Pendapatan Domistik Bruto (PDB). Besarnya PDB menunjukkan semakin banyak masyarakat yang mampu membayar pajak dan mempunyai penghasilan yang lebih tinggi dari Penghasilan Tidak Kena Pajak (PTKP). Oleh karena itu, tax ratio perpajakan juga akan semakin tinggi, sehingga penerimaan pajak dalam negeri meningkat. Dengan demikian, asumsi besarnya PDB sangat menentukan besar kecilnya penerimaan pajak dalam negeri yang bisa dihimpun dalam APBN.

Sebagaimana dipaparkan di atas, bahwa penerimaan pajak atau kontribusi pajak terhadap APB dari waktu ke waktu selalu meningkat, dan menjadikan sumber utama penerimaan negara yang fundamental. Artinya, penerimaan perpajakan sebagai sumber andalan untuk memperkuat basis penerimaan dalam negeri dalam upaya menunjang berlangsungnya kebijakan fiskal yang mandiri dan berkelanjutan (sustainbility).

Upaya untuk lebih memperbesar penerimaan dalam negeri terus diusahakan, sedangkan penghematan dalam pengeluaran terus diarahkan guna memperbesar tabungan pemerintah (government saving). Kenaikan pengeluaran selama ini selalu diusahakan agar sepadan dengan meningkatnya kegiatan pemerintah untuk mengelola hasil-hasil pembangunan dan pelayanan kepada masyarakat. Sekalipun disadari benar bahwa tidak mungkin melaksanakan pembangunan tanpa diimbangi oleh pengeluaran yang terus meningkat, namun penghematan dan pendayagunaan yang optimal di bidang pengeluaran tetap menjadi anutan.Oleh karena itu, dana dari penghematan merupakan sumber pembiayaan di samping pajak. Pajak yang dipungut oleh pemerintah atau diberikan oleh anggota masyarakat tanpa mendapatkan imbalan secara langsung itu harus dipergunakan untuk membiayai kepentingan umum (public service) atau disebut sebagai belanja negara

\section{Peranan Pajak Terhadap Pembangunan di Kabupaten Gowa}

Pajak merupakan sumber utama penerimaan negara yang digunakan untuk membiayai pengeluaran negara. Untuk melaksanakan pembangunan dibutuhkan dana yang tidak sedikit, dan ditopang melalui peneriman pajak. Oleh karena itu, pajak sangat dominan dalam menopang pembangunan nasional.

Seperti halnya yang diutarakan oleh Bapak Drs. Hasanuddin BM, yang mengatakan bahwa

"pajak merupakan sumber PAD yang paling berkontrribusi dalam pembangunan di

Kabupaten Gowa dari banyaknya jenis-jenis PAD yang ada, walaupun tidak bisa 
dipungkiri bahwa dengan pendapatan daerah yang ada dan kebutuhan masyarakat di Kabupaten Gowa itu sendiri bisa diibaratkan bahwa masih lebih besar pasak daripada tiang, yang artinya jumlah dana yang ada masih belum bisa memenuhi semua kebutuhan masyarakat baik dari segi sarana maupun prasarana di Kabupaten Gowa itu sendiri" 11

Grafik Realisasi Pendapatan Daerah Kabupaten Gowa Tahun 2016

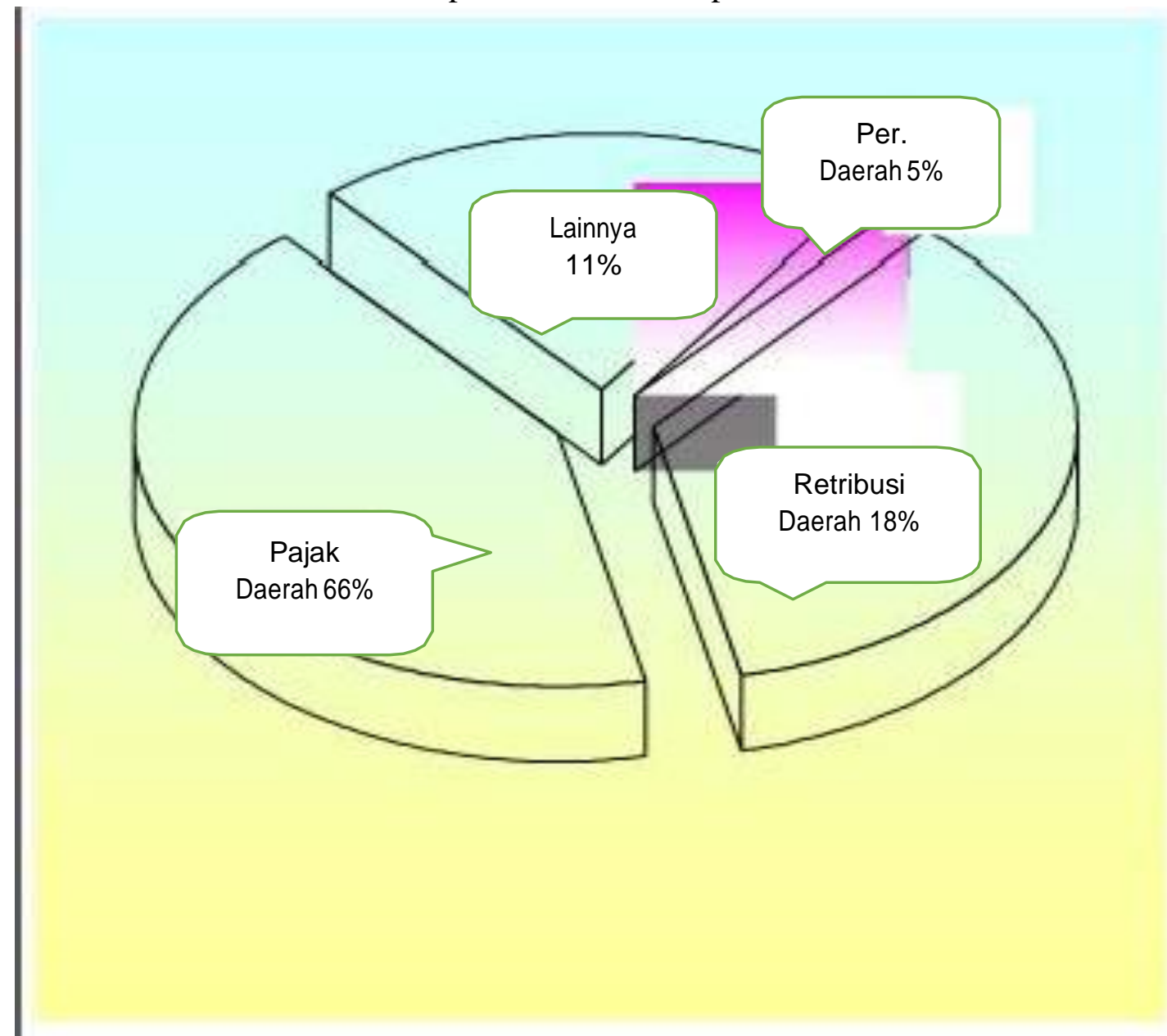

Sumber: Badan Pusat Statistik Kabupaten Gowa.

Pemungutan pajak tercantum dalam UUD 1945 yang dalam tataran pelaksanaannya melalui pembentukan undang-undang. Hal ini dimaksudkan dalam aspek hukum melahirkan suatu norma yang disepakati dan dipatuhi bersama. Namun demikian dalam pemungutan pajak banyak aspek yang mempengaruhi target-target yang akan dicapai, seperti laju pertumbuhan ekonomi, inflasi, nilai tukar, serta asumsi harga dan produk minyak mentah. Oleh karena itu, perlu strategi melalui perluasan basis pengenaan pajak, intensifikasi, dan penyuluhan kepada masyarakat dalam rangka meningkatkan kesadaran membayar pajak.

Untuk melaksanakan pembangunan, negara membutuhkan dana pembangunan yang tidak sedikit dimana kebutuhan dana pembungunan tersebut setiap tahun meningkat

${ }^{11}$ Hasanuddin, Sekretaris Kantor Badan Pendapatan Daerah Kabupaten Gowa, wawancara, 14 Agusutus 2017. 
seiring dengan peningkatan jumlah dan kebutuhan masyarakat. Kebutuhan dana tersebut terutama harus diperoleh dari sumber dalam negeri.

Dengan berpegang pada prinsip memberdayakan kemampuan dalam negeri maka kegiatan untuk meningkatkan penerimaan dalam negeri terus dilakukan oleh pemerintah. Penerimaan dalam negeri yang bersumber dari pajak dan bukan pajak ditingkatkan melalui intensifikasi dan ekstensifikasi. Fasilitas perpajakan guna mendorong peningkatan investasi tetap diberikan, sedangkan pembinaan iklim yang sehat bagi dunia usaha dilakukan dengan meningkatkan kepatuhan terhadap ketentuan-ketentuan perpajakan baik bagi wajib pajak maupun aparatur negara di bidang penerimaan negara.

Dasar hukum dari sumber penerimaan negara diatur dalam UUD 1945 Pasal 33 ayat (3), "Bumi dan air dan kekayaan alam yang terkandung di dalamnya dikuasai oleh negara dan dipergunakan untuk sebesar-besarnya kemakmuran rakyat". Pasal tersebut menjelaskan bahwa negara dalam hal ini pemerintah diberikan kewenangan oleh UUD 1945 untuk menguasai bumi, air, dan kekayaan alam yang terkandung di dalamnya untuk kemakmuran rakyat sebesar-besarnya. Artinya negara harus dapat memanfaatkan bumi, air dan kekayaan alam yang terkandung di dalamnya menjadi sumber penerimaan negara.

Sementara dasar hukum pemungutan pajak diatur dalam UUD 1945 pada pasal 23 ayat (2) "Segala pajak untuk keperluan negara berdasarkan undang-undang". Selain itu, dalam ketentuan lain tentang pemungutan pajak sehingga pungutan itu dinilai sah seperti Undang-Undang No. 36 tahun 2008 tentang PPh, UU No. 42 tahun 2009 tentang PPN. Pasal 23 ayat (2) UUD 1945 menetapkan bahwa setiap pajak yang dipungut oleh pemerintah harus berdasarkan undang-undang. Itu berarti bahwa setiap pungutan pajak harus terlebih dahulu mendapat persetujuan rakyat yang direpresentasikan dalam Dewan Perwakilan Rakyat (DPR) dalam bentuk undang- undang.

Pemerintah pada setiap tahun anggaran menyusun Rancangan Anggaran Pendapatan dan Belanja Negara (RAPBN) untuk diajukan kepada DPR agar memperoleh persetujuan dan kemudian diundangkan dalam bentuk undang-undang formal APBN. Pajak yang dipungut oleh pemerintah untuk membiayai kepentingan umum atau kepentingan rakyat itu sendiri. Tentunya ini mempunyai konsekuensi logis bahwa rakyat berhak untuk mengetahui jumlah dan bagaimana uang yang dibelanjakan untuk kepentingan umum.

Ciri dan corak dari sistem pemungutan pajak dalam undang-undang pasca pembaharuan perpajakan adalah:

1) Bahwa pemungutan pajak merupakan perwujudan dari pengabdian kewajiban dan peran serta Wajib Pajak untuk secara langsung dan bersama-sama melaksanakan kewajiban perpajakan yang diperlukan untuk pembiayaan dan pembangunan nasional.

2) Bahwa tanggung jawab atas kewajiban pelaksanaan pajak, sebagai pencerminan kewajiban di bidang perpajakan berada pada anggota masyarakat Wajib Pajak itu sendiri. Pemerintah (aparat perpajakan) hanya bertugas melakukan pembinaan, penelitian, dan pengawasan terhadap pelaksanaan kewajiban perpajakan Wajib Pajak berdasarkan ketentuan yang digariskan dalam peraturan perundang-undangan perpajakan.

3) Bahwa Wajib Pajak diberi kepercayaan untuk melaksanakan kegotongroyongan nasional melalui sistem menghitung, dan membayar sendiri pajaknya yang terutang (self assessment system), sehingga melalui sistem ini diharapkan dapat dilaksanakan 
dengan lebih rapih, terkendali, sederhana, dan mudah untuk dipahami oleh Wajib Pajak.

Berdasarkan ketiga prinsip pemungutan pajak di atas, Wajib pajak diwajibkan menghitung, memperhitungkan, dan membayar sendiri jumlah pajak seharusnya terutang sesuai dengan ketentuan peraturan perundang-undangan, sehingga penentuan penetapan besarnya pajak yang terutang berada pada Wajib Pajak itu sendiri. Selain itu Wajib Pajak juga diwajibkan untuk melaporkan secara teratur jumlah pajak yang terutang dan dibayar sebagaimana ditentukan undang-undang.

Dengan memperhatikan penjelasan di atas, khususnya tentang pungutan pajak dari masyarakat yang dilakukan oleh pemerintah maka dapat dimengerti bahwa dana masyarakat dalam bentuk pajak tersebut harus diperuntukkan bagi masyarakat sesuai fungsi alokasi, distribusi, dan stabilisasi dari APBN. Dalam hubungan tersebut, konstribusi penerimaan perpajakan terhadap APBN menjadi penting sehingga perlu dikaji ulang bagaimana agar penerimaan negara bisa terus ditingkatkan. Untuk mengkaji peranan konstribusi penerimaan perpajakan terhadap pembiayaan APBN. Seberapa besar peranan konstribusi penerimaan perpajakan terhadap pembiayaan APBN dibandingkan dengan penerimaan dalam negeri lainnya.

Namun demikian tantangan yang dihadapi juga dapat dipengaruhi dari berbagai faktor seperti laju pertumbuhan ekonomi, inflasi, nilai tukar, serta harga dan produk minyak mentah. Oleh karena itu, perlu strategi yaitu melalui perluasan basis pengenaan pajak, intensifikasi, dan penyuluhan kepada masyarakat dalam rangka meningkatkan kesadaran membayar pajak.

Seperti yang dikatakan oleh Bpk. Drs. Hasanuddin BM, "bahwa dalam optimalisasi pajak yang setiap tahun mengalami tren peningkatan, tidak bisa dipungkiri juga bahwa ada beberapa aspek yang mempengaruhi kurang maksimalnya pendapatan daerah di Kabupaten Gowa, yang secara garis besar beliau menyatakan bahwa faktor terbesarnya adalah karena kurangnya kesadaran masyarakat sebagai wajib pajak untuk melaporkan objek pajak yang mereka miliki dan kurangnya sumber daya manusia yang mampu untuk melakukan pemungutan pajak secara maksimal di Kabupaten Gowa"12

\section{KESIMPULAN}

Berdasarkan pembahasan diatas, penulis mengambil kesimpulan:

1. Bentuk penerimaan/pemungutan pajak atau sumber pendapatan daerah yang dilakukan di Kabupaten Gowa mengacu pada Undang-Undang Nomor 28 tahun 2009 tentang Pajak Daerah dan Retribusi Daerah yang ditindak lanjuti dalam Perda Nomor 11 tahun 2012, adapun laju pertumbuhan atau penerimaan pendapatan di Kabupaten Gowa setiap tahunnya semakin meningkat, sekalipun jumlah penerimaan pajak mengalami peningkatan setiap tahunnya namun penerimaan tersebut jika digabungkan dengan sumber pendapatan daerah lainnya belum bias memenuhi segala bentuk kebutuhan masyarakat di Kabupaten Gowa. Sekalipun demikian pajak adalah sumber utama pendapatan di Kabupaten Gowa yang memberikan kontribusi utama bagi laju pertumbuhan di Kabupaten Gowa itu sendiri.

2. Peranan pajak dalam pembangunan daerah di Kabupaten Gowa memiliki peranan yang penting, hal tersebut dibuktikan dengan jumlah pendapatan dari pajak yang lebih

${ }^{12}$ Hasanuddin, Sekretaris Kantor Badan Pendapatan Daerah Kabupaten Gowa, wawancara, 14 Agustus 2019. 
dominan dibandingkan dengan sumber PAD lainnya yang ada di Kabupaten Gowa, jenis pajak yang dominan di Kabupaten Gowa adalah BPHTB (Bea Perolehan Hak Atas Tanah dan Bangunan). 


\section{DAFTAR PUSTAKA}

Ali, Nuruddin, Mhd. Zakat sebagai Instrumen Kebijakan Fiskal. Jakarta: PT. Raja Grafindo Persada, 2006.

Assadiqie, Jimly. Perkembangan dan Konsolidasi Lembaga Negara Pasca Reformasi, (Cet. 2; Jakarta: Sinar Grafika, 2012.

Basri, Zainul Yusra, dan Mulyadi Subri. Keuangan Negara dan Analisis Kebijakan Utang Luar Negeri. (Ed. 1.,Cet.1; Jakarta: PT. RajaGrafindo Persada, 2003.

Bohari. Pengantar Hukum Pajak, edisi revisi 6 dan diperluas. Jakarta: PT. Raja Grafindo Persada, 2006.

Brotodihardjo, Santoso. Pengantar Ilmu Hukum Pajak. Bandung: Refika Aditama, 2002.

Gusfahmi. Pajak Menurut Syariah, Edisi Revisi 2. Jakarta: Rajawali Pers, 2011.

Hirawan, Susiyati, B. "Pembiayaan Pembangunan Perkotaan Melalui Pemanafaatan Instrumen Keuangan." Bogor: Ghalia Indonesia.

Inayah, Gazi. Teori Komperhensif tentang Zakat dan Pajak. Yogyakarta: Tiara Wacana, 2003.

Karim, A., Adiwarman. Ekonomi Makro Islam. Jakarta: Rajawali Pers.

Kusuma, Md. Krisna Arta Anggar dan Ni Gst. Putu Wirawati, E-jurnal akuntansi Universitas Udayan,5.3 (2013);574-585 (03 Maret 2017).

Mardiasmo. Otonomi dan Manajemen Keuangan Daerah (Percetakan Andi Ofset).

Parman, Ali. Pengelolaan Zakat (Disertai Contoh Perhitungannya). Makassar: Alauddin University Pers.

Rasyid, Soraya. Otonomi Daerah dalam Perspektif Sejarah. Makassar: Alauddin University Pres, 2011.

Saidi, Muhammad Djafar. Pembaruan Hukum Pajak, Edisi Baru. Jakarta: Rajawali Pers, 2014.

Sutedi, Adrian. Hukum Pajak dan Retribusi Daerah. (Cet, I; Bogor Selatan: Ghalia Indonesia, 2008.

Syukri, Ahmad. Hukum Tata Negara Islam. syukri-sjo.blogspot.com/2012/04/hukum tata Negara islam, (11 maret 2017).

Thoha, Mifta, Birokrasi Pemerintahan Indonesia di Era Reformasi, (Cet. 2; Jakarta: Fajar Interpratama Ofset, 2009.

Widjaja. Penyelanggaraan Otonomi di Indonesia. Jakarta: PT.Raja Grafindo Indonesia, 2005.

Yani, Ahmad. Hubungan Keungan Antara Pemerintah Pusat dan Daerah di Indonesia, edisi revisi dan diperluas. n.p.:Rajawali Pers, 2003. 